\title{
Why does cultural policy change? Policy discourse and policy subsystem: a case study of the evolution of cultural policy in Catalonia
}

\author{
Nicolás Barbieri \\ Universitat Autònoma de Barcelona \\ Institut de Govern i Polítiques Públiques \\ nicolas.barbieri@uab.cat \\ Draft
}

\begin{abstract}
Culture has come to play a fundamental strategic role in the territorial development that seeks to integrate knowledge economy with social cohesion, governance and sustainability. However, cultural policies have been unable to respond to the dilemmas and expectations that this new order presents. In order to appreciate the consequences of this process, it is essential to gain a better understanding of cultural policy change dynamics. This paper develops a framework for analysing cultural policy stability and change and applies it to the evolution of cultural policy in Catalonia. Both policy continuity and change are conditioned by the evolution of policy discourse on culture and the characteristics of the cultural policy subsystem. Within this framework, we also take into account the role of factors that are exogenous to the cultural domain. Lastly this paper addresses particular characteristics of cultural policy change in regions or stateless nations.
\end{abstract}

\section{Key words}

Cultural policy change, policy discourse, policy subsystem, national identity, Catalonia

When in May of 2008 the Parliament of Catalonia passed a law setting up the National Council for Culture and the Arts, and created the first mixed cultural policy system in southern Europe (bringing together both a department of culture and an arm's length administrative body), it was confirming two phenomena that are reflected in our initial quotes. Firstly, that culture (in its different senses) has come to play an increasingly fundamental strategic role in the territorial development that seeks to integrate knowledge economy with social cohesion, governance and sustainability. And secondly, that public policies in this field have been unable to respond to the often irreconcilable dilemmas and expectations that this new order presents. The history and evolution of cultural policy after World War II is related to these two phenomena. In order to appreciate the consequences of this process, it is therefore essential to understand the factors that determine significant policy change and continuity. We understand the direction of change in cultural policy as being a primary element for 
analysing of its consequences; an analysis of the distribution and exercising of power among those who participate in the formulation of public policy, those who see their preferences addressed and those who do not.

Political science offers an appropriate framework for analysing cultural policy change, and in turn, the particular characteristics of the cultural policy domain make it a scientifically relevant object of study for political science. However, there are still few politological studies, and even fewer in Spain, which analyse cultural policy domain and cultural policy change (Saint-Pierre 2004, Gray 2007, 2008, just to mention some of the few examples). Wimmer (2004) also notes that there is a remarkable predominance of scientific research on cultural policies undertaken from a purely economic or cultural management perspective.

The dominant paradigmatic models in contemporary political science have identified different factors in the logic of public policy stability and change. Methodologically, the study of policy change has become split between those who emphasise changes in individual interests and preferences, in institutional rules, or most recently, changes in ideational frameworks and in institutionalised discursive practices (Schmidt and Radaelli 2004, p. 185). Developing a new framework (including the generally missing politological approach) and applying it to cultural policy domain will help us to generate new knowledge about the way cultural policy is evolving. This is the specific objective of this article.

Due to the particular socio-historical context of cultural policies in Catalonia, this paper also addresses the analysis of relationships between identity and politics and the study of regions and stateless nations' cultural policies. With regard to Catalonia, there are several studies that address these issues as the main object, as the explanandum ${ }^{1}$, and we decided to focus on significant cultural policy continuity and change. Thus we will include national identity and particular characteristics of the government of culture in a sub-estate level within the two main explanatory factors. Firstly, this paper deals with the role of policy discourse in cultural policy change. We are interested in how and when policy discourse on culture can condition either significant continuity or significant change in cultural policy outputs. We nonetheless believe that a more complete explanation of policy change may be achieved by adopting a pluralistic

\footnotetext{
${ }^{1}$ See for example Crameri (2008), Lo Cascio (2008), Fernandez (2008), Keating (2001, 2003) or Negrier and Tomas (2003)
} 
approach that considers a wide variety of factors, and this is why we are also interested in the role of the policy subsystem ${ }^{2}$.

The first part of this article develops a framework for cultural policy stability and change analysis. The second part tests this framework and applies it to the analysis of the development of cultural policy in Catalonia. Lastly, this article also deals with the failure (in terms of benefits for the citizens) of any policy discourse that seeks to avoid relationships between culture and politics.

\section{A particular look at cultural policy change}

The aim of this section is to develop a framework for analysing cultural policy change dynamics. Although several researchers have made significant contributions, there is no critical, systematised corpus with common references in this regard. We shall therefore begin by outlining the current status of the issue. The systematization of this debate will allow us to identify some key explanatory factors which have not always been considered in cultural policy change analysis.

Firstly, while some research focuses on the history and evolution of cultural policies, other approaches study the taking of certain decisions that result in significant and even radical changes. The former include the famous passage from a model of democratisation to one of cultural democracy (Urfalino 1996), the consolidation of several variants of instrumental policy in culture and the arts (Wu 2002, Belfiore 2006, De Vereaux 2006, Gray 2007, Ratiu 2009), or the attempt to implement a systemic perspective (Cherbo and Wyszomirski 2000, Negrier 2003, Craik et al. 2003, Parker and Parenta 2009). Regarding the latter, research reveals certain policy cycles, usually within a multi-level government context and explicitly turning to theories of the policy process in some cases (Wyszomirski 1997, 2004, Shockley and Mc Neely 2009). Furthermore, there has been research that has attempted to explain the policy learning and change processes in greater detail (Saint-Pierre 2004, Singh 2008).

Secondly, another point of issue is how cultural policy change analysis takes exogenous or endogenous factors into account. Regarding the former, we should mention the role of the State and its different reactions to macro-social events: reconfiguration as a response to globalisation (Garcia Canclini 1995), privatisation as a

\footnotetext{
2 "Whatever the name one gives to these communities of specialists operating out of the political spotlight, most issues most of the time are treated within such community of experts" (True, Jones and Baugmartner 2007, p. 158).
} 
response to the crisis in the Welfare State (Wu 2002, Wimmer 2004), or "national aggrandisement" (McGuigan 2004, p. 62, Crameri 2008) and establishment of a selfdefining ideological framework (Coelho 2009) as a response to the weakness of the nation-State. Regarding the latter Parker and Parenta (2009) shed light on the role of frictions and contradictions within the cultural policy agenda in Australia, i.e. processes that encourage endogenous changes: strategic decisions made by the State or new balances between traditional actors.

There are also attempts to include both exogenous and endogenous factors in the policy change explanation, although this probably occurs more in theory than in empirically-supported research. The origin of a shift (towards the instrumentalisation of cultural policies) is explained by combining two elements. On the one hand, the expectations and pressures derived from the commodification of policy. And on the other hand, the structural weakness of the cultural policy sector (Gray 2007, 2008).

Particularly relevant (in both an empirical and analytical sense) are cultural policy change processes in the so-called stateless nations. In the case of Quebec, Saint-Pierre (2004) explains the appearance of the Politique Culturelle du Québec of 1992, using one of the most expanded theories of the policy process: the advocacy coalition framework $^{3}$. Thus, Saint-Pierre focuses primarily on endogenous factors of cultural policy change (for example ideational variations in the policy subsystem actors), and secondly on exogenous ones (government coalition change, constitutional debates). However, in another work, Gattinger and Saint-Pierre (2008) analyse the origins and evolution of cultural policy in Quebec (and Ontario), adopting a historicalinstitutionalist approach which helps to illuminate the distinctive policy and administrative trajectories of the cases examined. However, as they focus on the comparative cultural policy field, their explanation of cultural policy change describes more what is happening and less how and why: for example, in periods of significant continuity in policy contents, in crisis times or in openness to policy change processes.

Also in a context where national identities co-exist with a state identity, Galloway (2010) discusses the historical trajectory of national identity as an issue in arts policy, focusing on the development of the Arts Council in Scotland. The author does not analyse national identity as an explanatory factor for cultural policy stability and change; indeed, national identity is presented as an indicator of change in the model of

\footnotetext{
${ }^{3}$ Developed by Sabatier and Jenkins-Smith. See Sabatier and Weible (2007) for an updated analysis.
} 
arts governance. However, she highlights the way in which national identity helped determine the legitimacy of the Arts Council.

Lastly, a third non-systematised point of issue is the role of the structural conditions and actors' agency in explanations about cultural policy change. Broadly speaking, some studies agree on the evolutionary nature of cultural policy change and on the criticism of a structural determinism. On the one hand, we have the causal role of the interest of the actors within certain structural constraints. Hence, the economic, social and political changes that took place in the late 1970s and early 1980s were the basis of the ideological change that demanded new justifications for cultural policies. Despite these restrictions, the actors enjoy a certain degree of freedom and may decide to resort to the externalities of culture (Gray 2007, 2008). On the other hand, another explanation states that policy outcomes depend mostly on the policy-makers' interactions and learning, and highlights the actors' meta-power to change identities, interests and institutions (Singh 2008).

As we have already pointed out, one group of researchers explain policy stability and change as the convergence of conditions which are not controlled by any individual actor. The continuity of the federal arts policy in the USA during the 1970s and 1980s is thus explained by the action of a policy monopoly ${ }^{4}$ or "iron triangle" controlled by the NEA (Wyszomirski 2004, Shockley and Mc Neely 2009). With regard to policy change, the definition of policy issues plays a leading role. The way in which social problems arise and the public attention they get are essential elements(Wyszomirski 2004).

To conclude with this debate systematisation, on the one hand, in order to develop a more complete explanation of cultural policy change, we support a historical analysis that focuses on both exogenous and endogenous changes to the field of culture. It should also establish the relationship between socio-economic, structural factors and the agency of actors. On the other hand, it is important to consider both an evolutionary view of policy change (noting that not all change is evolutionary) and the moment's capacity for a significant policy shift. An analysis combining factors of institutional and ideational change becomes important (see Figure 1). Explaining change will help us to understand not only what is happening, but also (at least to some extent) how and why it happens. All of this without having to resort to a reductionist explanation of the collective action: an explanation that understands the development of cultural policies

\footnotetext{
4 "Monopoly on political understandings concerning the policy of interest, and an institutional arrangement that reinforces that understanding" (Baumgartner and Jones 1993, p. 6)
} 
as the mere result of the instrumentally motivated action of certain interest groups. Interest-based behaviour certainly exists, but in order to gain a better understanding of the development of cultural policies over long periods, we should go beyond rational choice-type approaches, its methodological individualism, and the idea that political actor's preferences are clearly-defined and constant.

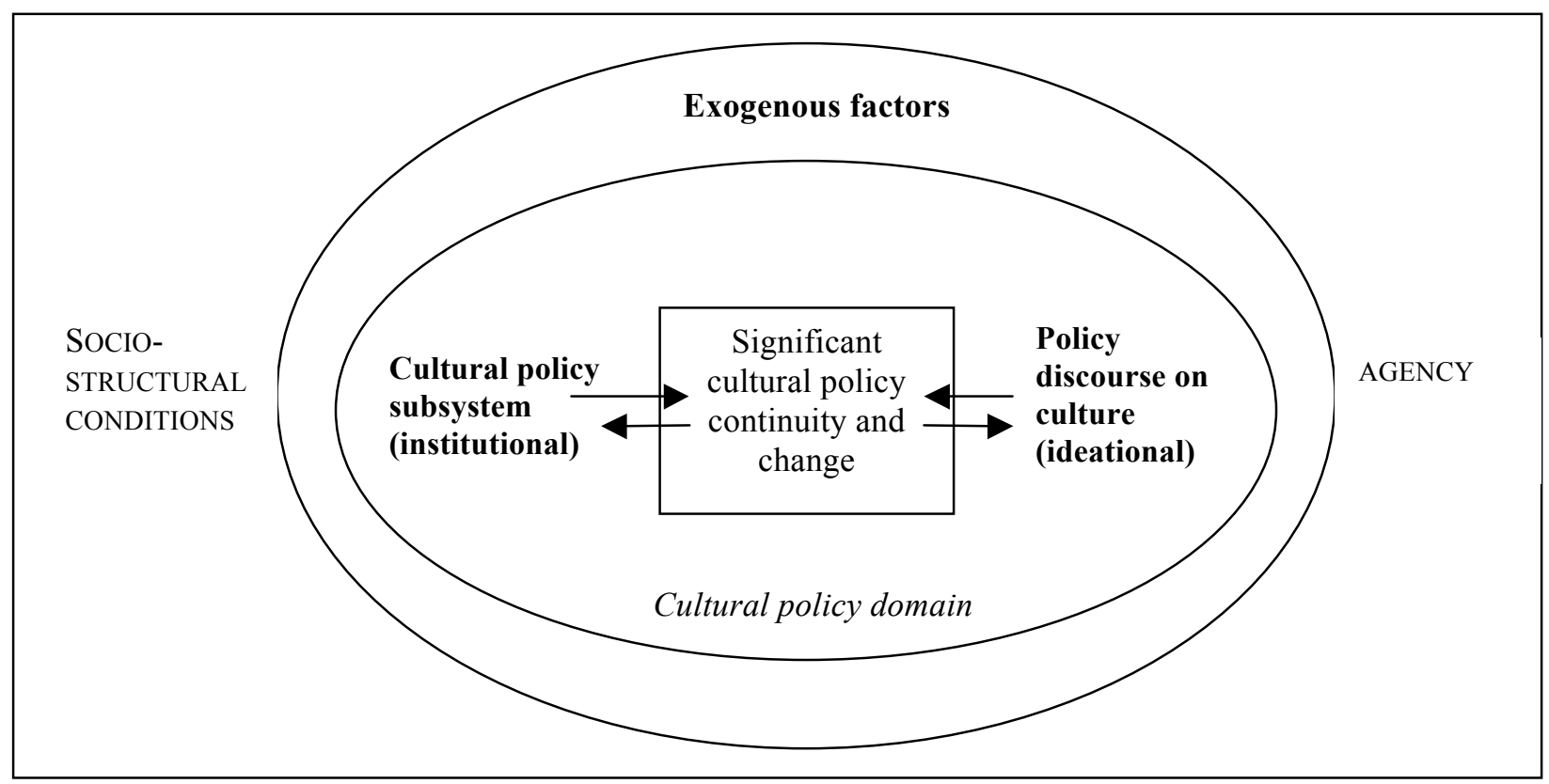

Figure 1. Framework for analysing processes of significant continuity and change in the contents of cultural policy

Our main hypothesis is that both the significant continuity and change of the contents of cultural policy over a long period of time are conditioned by the evolution of policy discourse on culture and the characteristics of the cultural policy subsystem. Within this framework, we also take into account the role of factors that are exogenous to the cultural domain. What do we understand by a policy discourse on culture? The representations of those involved in formulating policies in terms of what they understand, adopt and promote as "culture". Policy discourses are used as guides to action by defining the concepts and norms to be applied, identifying the problems to be solved, developing the policy instruments to be used, and framing the national policy discussion within a given policy arena (Schmidt 2001, 2002, Schmidt and Radaelli 2004). We therefore include not only the "cultural approach" to explanations of 
individual behaviour and the role of institutions ${ }^{5}$, but also the advances proposed by the discursive institutionalism framework, which allows us to specify the agency of ideas in policy image change. However, if discourses, ideas and frames of reference (a particular diagnosis and prognosis of problematic conditions) play a major role in the construction of policy problems, an explanation of cultural policy change should consider institutional restrictions. We have therefore added an analysis of the development of the policy subsystem and the level of the government's institutional legitimacy in the field of culture. In other words, the way in which the development of the characteristics of the cultural policy subsystem affects on the acceptance of the government's capacity to formulate cultural policies, in order to turn cultural policies into a public policy issue. This factor can be analysed by observing some of the elements described in the historical neo-institutionalism framework, and also in classic neo-elitism and neopluralism: the number and type of actors included in the subsystem, the position of power that each actor occupies, and the types of relationship they have.

\section{Catalonia as a study case: "a singular and universal culture"}

Our research is based on a case study of the evolution of the cultural policies of the autonomous government of Catalonia (1980-2008). In terms of specifying the object of study, we have decided to focus on the Generalitat's Department of Culture, since in Spain it is the Autonomous Communities which have, a priori, the majority of formal powers in the field of culture. We think it is a relevant case for understanding and illustrating our theoretical perspective. In an accelerated way over a period of less than 30 years, both the cultural policies of Catalonia and those of Spain have attempted to achieve a similar level of institutionalisation as that achieved by many European countries after World War II in under 60 years (Bonet 2001, Rodriguez Morato 2005, Rius 2005). Furthermore this process has developed in Catalonia with some unique features: the effects of a dictatorship that was devastating, among other things, for the institutionalisation of culture; a process of national and identity rebuilding, a legal and territorial framework established by the multi-level government of culture, etc. Thus, even if the case of Catalonia may echo similar tendencies in cultural policy in Europe since the middle of the 20th century, it would be difficult to identify, for example, a

\footnotetext{
${ }^{5}$ See for example Bevir and Rhodes $(2003,2006)$, whose approach has sparked a good number of recent European and Australian work in public administration and public policy that examine these issues.

6 "A singular and universal culture" was the motto for Catalan culture during a guest appearance ("guest of honour") at the Frankfurt Book Fair in 2007.
} 
clear passage from a model of democratisation to another of cultural democracy in its cultural policies. This is why, on the one hand, our analysis goes beyond the historicalinstitutionalist approach implemented by Gattinger and Saint-Pierre (2008). However, on the other hand, although a comparative perspective is beyond the scope of this paper, the reader will find some special references to the analysis of the development of cultural policy in Quebec and Scotland. The objective is not to compare but to use these cases (and to discuss the theoretical approaches presented above) in order to help us analyse and understand general processes of cultural policy stability and change and, particularly, in Catalonia.

Our definition of cultural policy is pragmatic, and has to do with the work carried out by public administrations engaged in this area. However, this type of analysis is constructionist since it assumes that social problems are interpretations of conditions that have been subjectively defined as problematic, and as such demand some type of ameliorative action. Problem definition is fundamentally a political exercise, a worldshaping exercise which includes images and the assignment of values to objects, people and events, i.e. the elements that operationalise policy and politics (Stone 2002, Ingram et al. 2007).

The methodology used is based on the decision to adopt a pluralistic approach in the perspectives, techniques and sources to be used. We have therefore combined policy frame analysis with content analysis of historical documents (parliamentary debates, records, laws and plans, publications of the political parties and their leading elite) and semi-structured interviews.

\section{Significant policy continuity: resistance and rebuilding}

Our aim in this section is to explain the first of our hypotheses, i.e. the way in which the significant continuity in cultural policies of the Generalitat de Catalunya has been conditioned for more than 15 years by the type of dominant policy discourse on culture and by the characteristics of the cultural policy subsystem.

\section{The first years of democracy: discursive and institutional context}

After a long and devastating dictatorship, the dominant discourse in the early 1980s between those responsible for the Department of Culture and Convergencia $i$ Unio (CIU- the nationalist conservative coalition party) presented the development of the cultural and political autonomy of Catalan society as a necessity. It was a discourse of a 
resistentialist nature, advocating national rebuilding. In a heterogeneous society, with a significant degree of immigration from the rest of the State and more than $40 \%$ of nonCatalan speakers (Idescat 1986), culture was understood as a core differentiating element, an identity and a national specificity of Catalonia. In short, it was a discourse with significant symbolic, idealistic, abstract and, in part, spiritual elements in terms of how culture was to be understood.

What degree of institutional legitimacy did the newly created Department of Culture have? What characteristics did the policy subsystem have? With regard to institutionalised rules, the return of democracy in Spain led to a transformation of the political and administrative structures of the State, marked by the transfer of certain powers to the autonomous communities, including those of culture. However, an imprecise sharing of powers would lead not only to continual tensions and conflicts between the state ministry responsible and the Department of Culture of the Generalitat, but also to a framework for developing the multi-level government of culture and the legitimacy of the Generalitat to formulate public policies in this area.

\section{Basic contents of the Generalitat's cultural policies}

During the early years of the new Generalitat, policies of direct intervention were developed and at the same time facilities were built. Continuity was manifested by the emphasis on policies for promoting the production, rather than the distribution, access to or consumption of culture. By way of an example, the cultural policy of the autonomous government was to encourage the proliferation of literary prizes, which were perceived as an instrument in ensuring the survival of the Catalan culture (Fernandez 2008, p. 209). It is worth noting that within the organisational structure of the Department of Culture, the Directorate General of Language Policy would remain without structural changes for over 20 years.

1985 saw the beginning of a brief period where the government of the Generalitat appeared to modify some of the basic elements of both its discourse and the patterns of its relationship with cultural agents. The Consell Assesor de Cultura de la Generalitat de Catalunya (an advisory council) was established (made up of cultural agents with a certain ideological plurality) and a national pact for culture was drawn up among the different public administrations. However, both measures failed: the national pact failed to win the support of all public institutions (among other reasons, because it was ultimately rejected by the then president of Catalonia), the advisory council was 
dissolved and the then Ministry of Culture resigned. The entire episode illustrates the confirming of a particular type of policy discourse, certain particular characteristics of the policy subsystem and thus the impossibility of establishing a change in the direction of cultural policies.

The rather discretionary and limited nature of the Generalitat's culture policy agenda can be seen in the absence of strategic and territorial planning. The vast majority of investment was devoted to the construction of major facilities in the city of Barcelona: a fact that indicates recognition of the place that Barcelona occupies in the cultural policy of the Generalitat. It was based on a double logic: infrastructure for production (over and above stimulation) and national infrastructures. In 1993, 33\% of the total budget of the Department of Culture in the area of the performing arts was devoted to the construction of the National Theatre of Catalonia, and 75 per cent of the budget devoted to the music area was earmarked for major projects involving traditional institutions (Baracelona's opera house The Gran Teatre del Liceu, The Palau de la Música and The Auditori) (Fina and Cubeles 1998).

\section{The role of policy discourse: a de-politicisation of culture?}

It has been argued that cultural standardisation (normalització) forms the cornerstone of the discourse of Catalan nationalism in matters of cultural policy. In line with the political transition after the dictatorship, this entailed the need to adopt pragmatic and politically neutral positions. As the Catalan Minister for Culture Joan Guitart pointed out, to standardise Catalan culture was to define it as a market (where goods are produced) and at the same time as an expression of national identity (Fernandez 2008, p. 82). If we wished to describe this policy discourse more precisely, rather than referring to cultural standardisation we should describe it as an attempt at de-politicising culture, or at least de-politicising cultural policies. Here we are not referring to the matter of the links between culture and the Catalan language, but rather to an attempt at disconnecting culture from the management of social conflict ${ }^{7}$.

It may even appear paradoxical that a nationalist government should not be more firmly commited to promoting the potential of culture as a strategic instrument, at least as far the public policies of the Department of Culture were concerned. However, the case of Scotland can be seen from a similar point of view. During the 1960s and 1970s, the

\footnotetext{
${ }^{7}$ A different strategy to the one adopted for the education policy and the media policy.
} 
public funding emphasis placed on major producing organisations was in harmony with the political response to emergent nationalism. The government endorsement of this idea highlights the attraction for politicians of flagships institutions as political symbols. Today, with the Scottish National Party in power, Gaelic may acquire this symbolic status (Galloway 2010, p. 9). As the author explains "ultimately, national cultures are sites of contestation, and public policy can operate either to open up or close down the possibilities for contest." (p. 9)

Culture in Catalonia is indeed ideological, yet during this long early period the government sought to avoid presenting it (to borrow words from Appadurai 1996, p. 44) as a political arena for conscious justifications, struggles and representations. In contrast, it was treated as a habit, a tacit sphere and it even seemed to seek to neutralise the logic of conflict that culture itself enshrines. The lack of explicit definition of certain elements and components of culture was more a political strategy than a lack of interest by those involved. Thus it was taken for granted that there was no need to explain what Catalan culture was, or discuss this core issue excessively, since it was something that was enshrined in the tradition and language, in the national identity.

The conception of Catalan culture carries with it an idea of what Catalonia is, thereby establishing a close link between the conception of Catalonia, and its cultural policies.

Catalunya is the long chain of generations, united by the Catalan language and tradition, that succeed each other in the territory where we live. The identity of Catalunya is, to a very large extent, linguistic and cultural.

(Jordi Pujol, President of Catalonia 1980-2003, quoted by Castells 2000, p. 51)

If language and tradition are the basis for the concept of Catalonia, then it makes sense that cultural policies have, for a long time, been channelled into developing these two areas.

The case of Catalonia allows us to understand the mechanism that leads to effectiveness, to the validity of policy discourse on culture. Defending, rescuing, and standardising culture (and the values associated with it) was considered to be a task of such an extent and importance that apparently only the Department of Culture had the capacity and status to take this on. In this manner, policy discourse conditioned the patterns of interaction with the rest of the participants involved and also the policy continuity over the years. The case of Quebec's cultural policy can be mentioned at this 
point, particularly during the 1970 s, when a new approach focusing on the national identity of Quebecers came to characterise cultural policy (Gattinger and Saint-Pierre 2008), and the government made culture a governmental question about national sovereignty and cultural survival (Saint-Perre 2004).

In line with the explanation provided by Schmidt (2008, p. 14), policy discourses may contain ideas that are convincing (in cognitive terms) and persuasive (in normative terms) by resonating with long-standing or newly emerging knowledge and values. However, the ideas in the discourse must not only "make sense" within a particular "meaning context"; agents may change (or maintain) this meaning context.

\section{Characteristics of the policy subsystem: from a policy monopoly to a decline in the institutional legitimacy}

As we have mentioned, the institutional context (an imprecise sharing of powers and a multilevel government of culture) explains in part why the government of the Generalitat, and more specifically the Department of Culture, was created with a high degree of legitimacy for intervening in the area of culture. Again, the examples of the cultural policies of Quebec and Scotland can be mentioned at this point. Regarding the former, the lack of clarity in the Constitution Act has meant that culture remains an area of concurrent jurisdiction, and has given rise to jurisdictional conflicts between the federal government of Canada and the Government of Québec (Saint-Pierre 2004, Gattinger and Saint-Pierre 2008). In the case of the latter, Galloway (2010, Galloway and Jones 2010) describes how the principle of devolved Scottish policymaking in the arts was intensely defended by the Scottish Committee of the Arts Council of Great Britain. Thus, although a comparative perspective requires a much more comprehensive analysis, we should recognise the way in which imprecise sharing of cultural powers leads to continual tensions between state governments and the governments of stateless nations. Yet at the same time, it leads to a situation where cultural powers are defended as a core value of self-government and where public and private actors recognise the legitimacy of the sub-state government to formulate cultural policies, in order to turn cultural policies into a public policy issue.

The original institutional context is a key explanatory factor, but going beyond a path dependency perspective calls for an analysis of how this significant initial degree of institutional legitimacy of the Department of Culture has evolved over a long time period. 
The number and type of participants included in the cultural policy subsystem in Catalonia was kept stable and a policy monopoly (Baumgartner and Jones 1993) was consolidated. The profile of the Ministers of Culture of the Generalitat was more that of an activist, a person of political action (of the party), than of an intellectual, or even less, of an artist. Those few intellectuals close to the Department of Culture came from the world of literature -a field clearly associated with language. The relations with sectors such as music or the visual arts, or with intellectuals who linked culture with economic and territorial development, were marked by something between indifference and conflict.

The type of relationship between the government and the rest of the participants in the subsystem, as well as the manner of approaching problem solving, was kept stable. The first years of democracy were marked by the links between the political elites of the government and certain actors from civil society that were culturally active during the years of the Franco regime. The relationship between the Generalitat, governed by CIU, and many local authorities, ruled by the Partit dels Socialistes de Catalunya (PSC), were based on confrontation and competition, particularly in the case of Barcelona City Council. The absence of a coordinative policy discourse regarding culture was also reflected in a very limited strategic design of cultural policies. The Department of Culture became almost the only policymaker responsible for setting policies.

\section{Crisis and opening up to policy change}

The case of Catalonia is useful for illustrating the importance of the development of policy discourses and policy subsystems as key factors able to condition policy change. We shall first of all examine the responses to the Generalitat's policy discourse on culture over two decades. On the one hand, the socialist's policy discourse on culture, voiced by many provincial and local governments (mainly in Barcelona), agreed on the need to implement a programme of cultural standardisation (normalització). However, culture was defined in a civic, citizen-based context, as an element of integration and diversity (cultural and linguistic), as a central element in the re-socialisation of cities after the dictatorship. This would only be a first step in the blurring and broadening of what was meant by culture. With the passing of the years, and in the face of a largely tacit and mistrustful discourse of the Generalitat, the socialist party would turn increasingly to complexity in defining culture and developing their policies. The criticism of the neglect of Barcelona's cultural potential was accompanied by the idea 
that Barcelona was, in cultural terms, a state capital, presented as modern and cosmopolitan - a capital without a country.

In addition, the mismatch between policy discourse, the content of public policies, institutions and socio-demographic characteristics and cultural production dynamics is a key factor in understanding the openness to change. At the end of the 1990s, Catalonia was experiencing the emergence of a new wave of immigration that was very different from that experienced during the dictatorship. The ideas and values regarding culture that had been useful with the return of democracy were seen to be completely outdated. As Parker and Parenta (2009) explain, institutional and ideational inconsistencies and contradictions are essential to understanding the process of change, although the interactions between actors who use different cultural policy frames are also an explanatory factor (Singh 2008). Thus, as early as 1994, Ferran Mascarell, who would later become the head of cultural policy of the Barcelona City Council and subsequently of the Generalitat, wrote: "Public policies continue to act as if they have a monopoly of all things cultural. As this is not the case, they appear less and less incisive and necessary, and remote from the real ways of producing, distributing and consuming culture." (Mascarell 2005, p. 177) ${ }^{8}$ And while his diagnosis is partial, it gives an indication of how cultural policies were to evolve in Catalonia in subsequent years: "Cultural policies have not been able to identify or explain what economic benefits a strong cultural sector produces for a city or country." (Mascarell 2005, p.178) ${ }^{9}$.

Finally, the progressive loss of the government of the Generalitat's institutional legitimacy to intervene in the cultural field reached its most significant point at the end of the decade. At that time there was a perception that public institutions were often outdated when it came to providing responses to social conflict. Some professionals in the cultural sector demanded the creation of an arts council that would in practice replace the executive functions of the Generalitat's Department of Culture. It was argued that administrative bodies were not a good instrument for cultural policies, and that public policy and administration were enemies of culture (Generalitat de Catalunya 2004). The institutional crisis in the cultural policy domain (and therefore the openness to policy change) could thus be explained in terms of the role of socio-economic, structural factors or even exogenous ones. Yet we should also consider the agency of cultural actors and their direct criticisms of the established system for government of

\footnotetext{
${ }^{8}$ Translation is mine.

${ }^{9}$ Translation is mine.
} 
culture. In the case of the development of the Politique Culturelle du Québec of 1992, Saint-Pierre (2004) highlights the impact of the general crisis of the Welfare State and the constitutional debates on cultural policy justifications. However, she also explains how the majority of cultural actors in Quebec seemed to agree with the diagnosis: the principal cause of the problematic situation of culture was the governmental model of action and coordination in the field of culture.

\section{Significant policy change and disorientation}

The change of the coalition government in the Generalitat de Catalunya in 2003 meant the arrival of the PSC in the Department of Culture. However, this significant perturbation from outside of the subsystem, even if it is a key factor, does not explain the process of policy change. Indeed, significant changes in the formulation of policies and their content began at the end of the 90 s on three levels (see Table 1). Significant initiatives included the creation of the Catalan Institute of Cultural Industries (ICIC) in 2000 , and from the perspective of governance, the drafting of the White Paper on Cultural Industries (Generalitat de Catalunya 2002), an enterprise involving different sectors, professional specialists and scientists. The Institut Ramon Llull (IRL) a body aimed at promoting the Catalan language and culture abroad was also created in 2002.

Table 1. Policy contents of the Department of Culture

\begin{tabular}{|l|l|l|}
\hline & Policy continuity & Policy change \\
\hline $\begin{array}{l}\text { Type of policy } \\
\text { contents }\end{array}$ & $\begin{array}{l}\text {-Emphasis on cultural } \\
\text { production and diffusion } \\
\text {-Major national facilities } \\
\text {-Legislation in language and } \\
\text { heritage }\end{array}$ & $\begin{array}{l}\text {-Diversification of intervention: } \\
\text { (industrial) production and } \\
\text { distribution. } \\
\text {-Attempt at strategic (economic) } \\
\text { planning with cultural sectors } \\
\text {-Legislation in cultural industries } \\
\text { and creation. }\end{array}$ \\
\hline $\begin{array}{l}\text { Institutional } \\
\text { arrangements }\end{array}$ & $\begin{array}{l}\text {-Stabilisation of the } \\
\text { organisational chart (cultural } \\
\text { promotion, heritage, language) } \\
\text {-Failure of the national pact and } \\
\text { the advisory council }\end{array}$ & $\begin{array}{l}\text {-Significant changes in the } \\
\text { organisational chart. } \\
\text {-Catalan Institute of Cultural } \\
\text { Industries (2000) } \\
\text {-Ramon Llull Institute (2002) } \\
\text {-National Council for Culture and } \\
\text { the Arts (2008) }\end{array}$ \\
& $\begin{array}{l}\text { Budgetary } \\
\text { development }\end{array}$ & $\begin{array}{l}\text {-Significant increase } \\
\text {-Diversification and transfers to } \\
\text { agencies, consortiums and public } \\
\text {-Emphasis on direct } \\
\text { lantervention and } \\
\text { institutionalisation }\end{array}$ \\
\hline
\end{tabular}


For its part, the organisational chart of the Department of Culture experienced significant changes that would lead to the creation of the National Council for Culture and Arts in 2008. Lastly, the call for a complex role for culture led to a significant increase in the budget for the Department of Culture of the Generalitat. Doubling the budget became an explicit objective, a manifesto commitment.

The following section examines the way in which this period of significant change in cultural policies of the Generalitat has been conditioned by two factors. On the one hand, the consolidation of a new policy discourse that proposed the expansion of the idea of culture; and on the other, the government's attempt to regain its institutional legitimacy.

\section{The role of policy discourse: change and disorientation?}

From the end of the 1990s, a series of changes took place in the dominant policy discourse on culture within the Generalitat. The representation or concept of Catalonia that has ended up being consolidated in the policy discourse is that of an enterprising and innovative society devoted to excellence, and one that is able to compete in the world. National identity is at once a condition of existence and a tool of competition. As in a good number of European cultural policies (from European Capitals of Culture to the European year of Creativity and Innovation), culture is understood definitively as an element of competitiveness, with its condition being recognised as a stage, as an arena for performances, conscious choices and justifications that are explicit and no longer tacit. In the case of Scotland, the question of "national culture" was a central aspect of its first National Cultural Strategy in 2000, and is now a formal part of the Arts Council's funding framework (Galloway 2010). This explains why the author understands national identity as an indicator of policy change, and analyses it as the explanandum. This policy change process is explained partly in terms of political or constitutional change (exogenous factors) but mainly in terms of the reconceptualisation of culture since the 1980s, as an economic resource, embodied in "creative industries/creative economy" thinking, which contributes to national economic competitiveness. The development of the Politique culturelle du Québec in 1992 was also stimulated by a constitutional debate, but was particularly rooted in a process of change in the conception of culture begun in the 1980s, a process "which aligns culture and the economy and associates culture with industry" (Gattinger and Saint-Pierre 2008, 
p. 345). One of the main objectives of the new policy was to affirm Québec's cultural identity while remaining "open to the world".

The three cases show how changes in relationships between culture and economics are involved in process of policy change. Yet more than this, our case also shows a process of change in the association between the conception of Catalonia and its cultural policies. Policy discourse defines not only the technical purposes and objectives of a policy programme but also the political goals and ideals, identifying them with traditional or modern values (Schmidt 2008). National identity and national culture are at the core of policy discourse on culture, so they can be analysed not only as an indicator of change in the model of culture governance or in the policy contents but also as a key factor explaining cultural policy stability and change.

In the last two CIU governments, globalisation was diagnosed as being one of the major threats to Catalan culture. In the prognosis the role of cultural industries arose, and public intervention in this area was justified as being not only a promoter of economic development, but also as a guarantor of the existence of products related to Catalan culture. Some ideas and values that the PSC had been advocating in its policy discourse on culture were incorporated, such as the need for a certain complexity and capacity for strategic planning and analysis (especially economic analysis) of cultural policies, or a closer relationship with cultural industry sectors.

With the arrival of the PSC in the Department of Culture the explicit expansion of the semantic field of culture continued. If at first, for policy discourse on culture, only the Department was capable of taking on and directing policy, the new period recognised the need to involve a part of the remaining cultural agents (local administrations, cultural sectors) in the development of policies. It is worth clarifying though that this alone does not signify the democratisation in the formulation of the objectives of cultural policies.

In the final years of the period studied, the progressive nationalist party Esquerra Republicana de Catalunya took over the running of the Department of Culture of the Generalitat de Catalunya. In contrast to the risk that Catalan culture ran during the dictatorship, the challenge presented by the policy discourse was to adapt, to coexist. And the prognosis thus voiced the need for some cultural policies which would divert resources to distribution and promotion.

And lastly, why is this process of change associated with disorientation? The policy discourse on culture was constructed based on permeability; appealing to the future and 
to policy change. What is lost in ideological coherence is gained in the flexibility arising from the use of a wide range of concepts and norms, including some of which are contradictory. This policy discourse on an expanded concept of culture was a reflection and at the same time a condition of the lack of boundaries in the area of cultural policies, which in large measure have allowed significant change to take place and at the same time disorientation and weakness. Cultural policy was highlighted as an instrument of economic development and social cohesion, and the excellence of the sector and quality were held up as a criterion of measurement.

The re-introduction of the concept of excellence within the dominant policy discourse on culture was presented as a means of removing cultural policies from the ideological and (party) political stage - one of the main criticisms aimed at the cultural policy of the CIU government. Yet, once again, it also involved an attempt (always unattainable) to remove political and ideological content from cultural policies, thus circumventing the implications that these might have in the management of social conflict. A policy discourse on culture may claim that ideology and politics should have no place in cultural policies, but this is itself a political and ideological position.

\section{Characteristics of the policy subsystem: regaining institutional legitimacy}

Since the end of the 1990s the well-defined institutional structure of policy making (policy monopoly) in Catalonia has suffered modifications. It is significant that, in the final years of the period studied, the Department of Culture was one of the main political actors in a number of incentives that provoked important public debates about Catalan identity and culture. Yet it does not always prove that variations have an origin outside of the subsystem, within the spotlight of macro politics, as True et al. (2007, p. 158) argue. Rather the evidence in our case shows that it depends on a) how the government seeks to recover a position of power based on an increase in the possession of legal, economic, cognitive, and symbolic resources; and b) how the type of relationship between the government and the rest of the actors in a policy subsystem is modified, as well as the way problem solving is approached. In this sense, the appeal to complexity was reflected in the attempt to achieve a multilevel government of culture. Thus the first strategic agreements on cultural policy between the Generalitat, governed by CIU, and Barcelona City Council, governed by the PSC, were signed. This process has also led to the consolidation of certain private cultural actors as policymakers and at the same time recipients of cultural policies. The place occupied by the coalition 
Platform for an Arts Council as the principal interlocutor in the process of creation of this body exemplifies this situation

And lastly, an attempt was made to encourage the autonomous development of the culture industry, but with a special role for the state in protecting the cultural traditions of a nation, in national building. Faced with a dilemma of this type, the solution put forward was that of desetatisation (Craik et al. 2003), i.e. reducing direct government intervention and the adoption of strategies such as privatisation or autonomisation: proliferation of agencies, subcontracting, institutional reforms based on the principle of arm's length, etc.

\section{Conclusions}

In this paper we have set out the relationships between policy discourse, policy subsystem and cultural policy stability and change.. Policy discourses on culture are in competition; more than ideologies, they involve frames of reference, which are redefined by their use in the political-institutional arena. The ideas, values and interests that the different political actors bring to the public sphere, and their interpretations mediated by the restrictions in this area, determine policy change and continuity. The construction of a dominant discourse is a political process marked more by the rationality of the collective action than by any kind of instrumental rationality.

A process of this kind can be seen in the construction of the policy discourse on culture in Catalonia. For many years, the government kept the idea of culture (and the concept of Catalonia) within a frame of reference. Ambiguity was a key factor to keeping this idea within tacit limits which were, apparently, unquestionable. The policy discourse on culture was underpinned by the fear of social rupture and distrust: the problem was constructed in such a way that practically the only possible solution was the preferred one. In addition, a policy monopoly became consolidated and the policy subsystem was ruled by a responsible, well-defined institutional structure of policy making. The combination of these elements determined the existence of a period of significant continuity of the contents of cultural policy.

The empirical evidence revealed in our case shows that openness to change regarding cultural policies is not always explained mainly by mobilising interest or by socioeconomic structural changes. Sometimes the openness to change is driven by a decreased capacity of the dominant policy discourse to legitimise political actions (Schmidt 2001, 2002). Our analysis sheds light on the importance of analysing the 
incompatibility between policy discourses, policy contents, institutions and sociodemographic characteristics and cultural production dynamics. Furthermore, special attention must be paid to the penetration of ideas and values from opposing policy discourses on culture. The very same confrontation with alternative discourses may decrease the validity of any dominant idea and value. Lastly, the analysis should consider the internal contradictions of the discourse as the cause of the decreased capacity to justify political actions.

A second explanatory factor of the aforementioned change is the loss of the institutional legitimacy of the government to intervene in the cultural field. It must be understood not only as a decreased identification of the capacities of a particular government body to implement a political programme, but also as a loss of legitimacy of cultural policy in general. That is the scenario the Generalitat's Department of Culture was faced with in the late $90 \mathrm{~s}$. There thus began a period in which the government decided to introduce policy changes and seek new goals and intervention tools which would allow it to recover its institutional legitimacy.

Looked at thus, the significant change of policy contents is a process that goes beyond an external change to the subsystem. Thus a significant perturbation from outside the subsystem (such as the change in the coalition of the government of Catalonia after 23 years) represented a determining, though insufficient, cause for significant policy change. A change in the policy discourse acted as a catalyst (and at the same time a prerequisite) for significant policy change. The relationship between policy discourse and policy change is not a one-way relationship but rather a dynamic and mutually constitutive one, and the idea that policy discourse conditions the processes of policy stability and change recognises that changes within policy discourses are involved in these processes.

Finally, some qualifications are required regarding the idea that there is room for optimism in applying national-level approaches to sub-national cultural policy studies (Gattinger and Saint-Pierre 2008, p. 348); at least in things related to policy change analysis. National identity and particular characteristics of the government of culture in stateless nations can be analysed as indicators of change in policy contents (as the explanandum). This is in tune with a historical-institutionalist approach based on the description of the trajectories of the study cases, and developed for nation-state cultural policy analysis. But this paper has shown that those elements can also be analysed as key explanatory factors for general cultural policy change. Thus, in order to develop a 
more comprehensive understanding of this process we should consider thoroughly both the structural factors and the agency of cultural actors; we should analyse not only institutional constraints but also (limited) degrees of autonomy. With regard to this, developing frameworks for analysing cultural policies in stateless nations may help to improve state-level approaches.

We would like to end with a reflection on the failure (in terms of benefits for the citizens) of any policy discourse that seeks to present culture as something that is free, balanced and politically neutral: which avoids defining its boundaries and implications by appealing either to a tacit construction (culture as a given thing) or to complexity (culture as the sum of all things and belonging to everyone). As Eagleton (2000, p. 33) affirms, a sense in which culture brings about its own failure is that which presents it as an antidote, capable of balancing and keeping the spirit away from sectarian things; a notion where unity is inherently preferable to conflict. A policy discourse of this kind has contributed to a situation where, in Catalonia, and in a large part of Europe, cultural policies are seen as disorientated, and tend to justify their task based on their contribution to objectives and values that are circumstantially in vogue. The eminently political nature of culture has been identified as a problem to be solved by means of public policies rather than as an opportunity.

If we intend to turn the cultural policy into a transforming sphere rather than just a functional activity (describing and reproducing the social order), the relationships between culture and politics should not be precluded (or abolished). Identifying, criticising and transforming such relationships may be a more reasonable way to both construct public policy itself and to analyse it scientifically. To sum up, we should ask ourselves, what are cultural policies for? How and why do they change? These are some of the further questions around which cultural policy analysis will be defined as an independent, social and scientifically relevant discipline.

\section{REFERENCES}

- Appadurai, A., 1996. Modernity at large: Cultural dimensions of globalization. Minneapolis: University of Minnesota Press.

- Baumgartner, F. and Jones, B., 1993. Agendas and instability in American politics. Chicago: University of Chicago Press.

- Belfiore, E., 2006. The social impacts of the arts - myth or reality? In: M. Mirza, ed. Culture Vultures: Is UK arts policy damaging the arts? London: Policy Exchange, 143-161.

- Bevir, M. and Rhodes, R. A. W., 2003. Interpreting British governance. London: Routledge. 
- Bevir, M. and Rhodes, R. A. W., 2006. Governance stories. London: Routledge.

- Beyme, K., 1994. Teoría política del siglo XX: de la modernidad a la posmodernidad. Madrid: Alianza Editorial.

- Bonet, L., 2001. Les polítiques culturals a Catalunya: un espai d'acords bàsics en un context d'alt dinamisme. In: R. Gomà and J. Subirats, eds. Govern i polítiques públiques a Catalunya (1980-2000): Autonomia i benestar. Barcelona: Edicions Universitat de Barcelona, 303-325.

- Bustelo, M. and Lombardo, E., 2007. Políticas de igualdad en España y en Europa: afinando la mirada. Madrid: Cátedra,

- Castells, M., 2000. The Rise of the network society, Oxford: Blackwell.

- Cherbo, J. and Wyszomirski, M. 2000. The Public life of the arts in America. New Brunswick: Rutgers University Press.

- Craik, J., Mcallister, L. and Davis, G., 2003. Paradoxes and contradictions in government approaches to contemporary cultural policy: an Australian perspective. International Journal of Cultural Policy 9 (1), 17-33.

- Crameri, K., 2008. Catalonia: national identity and cultural policy, 1980-2003. Cardiff: University of Wales Press.

- Coelho, T., 2009. Diccionario crítico de política cultural. Barcelona: Gedisa.

- De Vereaux, C., 2006. Any Way the Wind Blows: Changing Dynamics in American Arts Policy. Journal of Arts Management, Law and Society 36 (3), 168-180.

- Eagleton, T., 2000. The idea of culture. Oxford: Blackwell.

- Fernández, J. 2008. El malestar en la cultura catalana. Barcelona: Empúries.

- Fina, X. and Cubeles, X., 1998. La cultura a Catalunya, Barcelona: Fundació Jaume Bofill.

- Fina, X., 1999. La responsabilidad de la sociedad civil en el sector cultural. In: J.Subirats, ed. ¿Existe sociedad civil en España? Madrid: Fundación Encuentro.

- García Canclini, N., 1995. Hybrid cultures. Minneapolis: University of Minnesota Press.

- Generalitat de Catalunya, 2003. Llibre blanc de les indústries culturals a Catalunya. Barcelona: Universitat de Barcelona.

- Galloway, S. 2010. Arts policy and national identity: the history of the Arts Council in Scotland. International Conference on Cultural Policy Research, Jyväskylä, Finland, 24-27 August 2010.

- Galloway, S. and Jones, H.D. 2010. The Scottish dimension of British arts government: a historical perspective. Cultural Trends 19 (1-2), 27-40.

- Gattinger, M. and Saint-Pierre, D. 2008. Can national cultural policy approaches be used for sub-national comparisons? An analysis of the Québec and Ontario experiences in Canada. International Journal of Cultural Policy 14 (3), 335-354.

- Generalitat de Catalunya, 2004. Document per a l'establiment del Consell de la Cultura i de les Arts a la Generalitat de Catalunya [online]. Generalitat de Catalunya. Available from: http://www20.gencat.cat/docs/CulturaDepartament/Cultura/Documents/Arxiu/comissionatcca documents.htm\%20-\%20establiment_cca.pdf (accesed 15 January 2010)

- Gray, C., 2007. Commodification and instrumentality in cultural policy. International Journal of Cultural Policy 13 (2), 203 - 215.

- Gray, C., 2008. Instrumental policies: causes, consequences, museums and galleries. Cultural trends 17 (4), 209-222

- Hesmondhalgh, D., 2005. Media and cultural policy as public policy. International journal of cultural policy 11 (1), 95-109.

- IDESCAT. 1986. Cens lingüístic. Barcelona: Generalitat de Catalunya.

- Ingram, H., Schneider, A.and deLeon, P. 2007. Social Construction and Policy Design. In P. Sabatier ed. Theories of the policy process. Oxford: Westview Press. 93-126.

- Keating, M., 2001. Rethinking the region. Culture, institutions and economic development in Catalonia and Galicia. European Urban and Regional Studies, 8(3): 217-234.

- Keating, M., Loughlin, J. and K. Deschouwer. 2003. Culture, Institutions and Regional Development: a Study of Eight European Regions. Cheltenham: Edward Elgar

- Kingdon, J., 1984. Agendas, Alternatives and Public Policies. Michigan: Harper Collins.

- Lewis, J. and Miller, T., ed. 2003. Critical Cultural Policy Studies: A Reader, Oxford: Blackwell. 
- Lo Cascio, P., 2008. Nacionalisme i autogovern. Catalunya 1980-2003. Barcelona: Afers

- Mascarell, F., 2005. La Cultura en l'era de la incertesa. Barcelona: Roca.

- McGuigan, J., 2004. Rethinking Cultural Policy. Milton Keynnes: Open University Press.

- McRobbie, A., 1996. All the world's a stage, screen or magazine: When culture is the logic of late capitalism. Media, Culture and Society, 18 (3). 335-342.

- Négrier, E., 2003. Las políticas culturales en Francia y España. Una aproximación nacional y local comparada. Working Papers Institut de Ciències Polítiques i Socials (226).

- Négrier E. and Tomàs M. 2003. Temps, pouvoir, espace la métropolisation de Barcelone. Revue française d'administration publique 107. 357-368.

- Parker, R. and Parenta, O., 2009. Multi-level order, friction and contradiction: the evolution of Australian film industry policy, International Journal of Cultural Policy, 15 (1), 91-105

- Ratiu, D. 2009. Cultural Policy and Values: Intrinsic versus Instrumental? The Case of Romania. Journal of Arts Management, Law and Society 39 (1), 24-44.

- Rius, J., 2005. Un nou paradigma de la política cultural. Thesis (phd). Universitat de Barcelona.

- Rodriguez Morató, A., 2005. La reinvención de la política cultural a escala local: el caso de Barcelona. Sociedade e Estado 20 (2), 351-376.

- Sabatier, P. and Weible, M. 2007. The Advocacy Coalition Framework: innovations and clarifications. In P. Sabatier ed. Theories of the policy process. Oxford : Westview Press. 189220.

- Saint-Pierre, D., 2004. La Politique culturelle du Québec de 1992 et l'Advocacy Coalition Framework: Une étude de cas dans le domaine de la culture. Canadian Journal of Political Science / Revue canadienne de science politique 37 (3), 561-580.

- Sanchez de la Barquera, H. (in press). La cultura y la Ciencia Política comparada. Estudios de Política y Sociedad.

- Schmidt, V., 2001. The politics of economic adjustment in France and Britain: when does discourse matter? Journal of European Public Policy 8 (2), 247-264.

- Schmidt, Vivien. 2002. Does Discourse Matter in the Politics of Welfare State Adjustment? Comparative Political Studies 35 (2), 168-193.

- Schmidt, Vivien. 2008. From historical institutionalism to discursive institutionalism, Council for European Studies (Chicago, March 6-8, 2008)

- Schmidt, V. and Radaelli, C. 2004. Policy Change and Discourse in Europe: Conceptual and Methodological Issues. West European Politics 27 (2), 183 - 210.

- Shockley, G, and Mc Neely, C., 2009. A Seismic Shift in U.S. Federal Arts Policy: A Tale of Organizational Challenge and Controversy in the 1990s. Journal of Arts Management, Law and Society 39 (1), 7-23

- Singh, J.P. Agents of Policy Learning and Change: U.S. and EU Perspectives on Cultural Trade Policy. Journal of Arts Management, Law and Society 38 (2), 141-159.

- Stone, D., 2002. Policy Paradox and political reason, New York: Norton.

- True, J., Jones, B. and Baumgartner, F. 2007. Punctuated-equilibrium theory: Explaining stability and change in American policymaking. In: P. Sabatier, ed. Theories of the policy process. Oxford: Westview, 155-187.

- Urfalino, P., 1996. L'invention de la politique culturelle. Paris: Hachette.

- Wimmer, M., 2004. The Political Dimensions of Cultural Policy - The Need of Policy Analysis in the Field of Cultural Policy. International Conference on Cultural Policy Research, Montreal, Canada, August 25-28, 2004.

- Wyszomirski, M., 1995. The politics of arts policy: Subgovernment to issue network. In: K. Mulcahy and M. Wyszomirski, eds. America's commnitment to culture: Government and the arts, Boulder, CO: Westview, 47-73.

- Wyszomirski, M., 1997. Through the Policy Window: The Context of Cultural Policy: Introduction to the Symposium. Arts Education Policy Review 98 (5), 9-11

- Wyszomirski, M., 2004. From public support for the arts to cultural policy. Review of Policy Research 21, 469-84.

- Wu, C., 2002. Privatising culture. New York: Verso books. 